\title{
Micro-Enterprises' Digital Marketing Tools for Building Customer Relationships
}

\author{
TUULIA NIKUNEN \\ University of Oulu, Finland \\ tuulia.nikunen@student.oulu.fi \\ MARTTI SAARELA \\ University of Oulu, Finland \\ martti.saarela@oulu.fi \\ EEVA-LIISA OIKARINEN \\ University of Oulu, Finland \\ eeva-liisa.oikarinen@oulu.fi \\ MATTI MUHOS \\ University of Oulu, Finland \\ matti.muhos@oulu.fi \\ LARI ISOHELLA \\ University of Oulu, Finland \\ lariisohella@gmail.com
}

The digital marketing environment is changing rapidly, and, for micro-enterprises, digital marketing is currently a vitally important opportunity. Attracting customers, engaging customers' interest and participation, retaining customers, learning customers' preferences and relating to customers are key strategies in building strong customer relationships. However, many enterprises ignore longer-term aspects of managing customer relationships. The study sought to contribute to a more in-depth understanding of micro-enterprises' current strategies in terms of new digital marketing tools that foster stronger customer relationships. Based on interviews of two digital marketing service providers, this paper describes how their micro-enterprise clients use digital marketing tools through the five elements of building customer relationships. The findings highlight the importance of a practical understanding of digital marketing tools, as the digital marketing environment changes rapidly. The human capital and digital tool knowledge of micro-enterprises' owner-managers have a great impact on these firms' digital marketing and, ultimately, their success.

Key words: digital marketing, micro-enterprise, digital marketing tool, customer relationship https://doi.org/10.26493/1854-4231.12.171-188 


\section{Introduction}

Digital marketing creates opportunities to develop successful businesses in a way that previously was not possible for small companies (Eid and El-Gohary 2013), and is becoming an increasingly important source of competitive advantage in both business-to-business and business-to-consumer markets (Leeflang et al. 2014). The existing literature shows that digitalisation in all its variations is connected to small businesses' growth, performance and competitiveness (Taiminen and Karjaluoto 2015). This study focuses on microenterprises, which are defined as 'enterprises which employ fewer than 10 persons and whose annual turnover and/or annual balance sheet total does not exceed two million Euros' (European Commission 2003). Micro-enterprises are an extremely heterogeneous group, so this concept can include, among other formats, start-up companies, family businesses and self-employed managers with one or more employees (Devins et al. 2005). Micro-enterprises are characterized by a paucity of resources and expertise (Barnes et al. 2012).

Gilmore, Gallagher, and Henry (2007) state that communication through the Internet provides an opportunity for companies that have limited capital to succeed as international marketers in the early stages of their development. According to Bordonaba-Juste, Lucia-Palacios, and Polo-Redondo (2012) and Lipiäinen (2014), the one of the main aspects that influence the use of e-business is size; micro-enterprises utilize digital tools less likely than larger firms do. Moreover, marketing in small companies is different than in larger organisations, and researchers assert that company size must be taken into account in marketing planning (Gilmore et al. 2007). For example, owner-managers' human capital is an important factor in small and medium-sized enterprises' digital marketing, including their marketing manager's knowledge of digital channel alternatives (Taiminen and Karjaluoto 2015). Clark and Douglas (2014) state that the role of human capital in the micro-enterprises' growth can be even greater than in small companies. Hereby micro-enterprises' owner-managers' or solo-entrepreneurs' personal objectives and characters are essential elements in utilizing digital marketing tools (Clark and Douglas 2014).

Given that micro-enterprises' significance to economic growth and employment is undisputed; the micro-enterprise sector appears to be a pivotal feature of successful economies (Sinisammal et al. 2014; Yrityskatsaus 2014). However, most digital marketing and e-

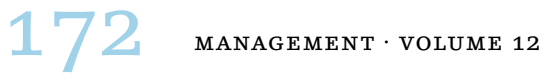


business adoption studies have focused on larger companies, and, thus, little research focused on micro-enterprises exists in this area (Donnelly et al. 2015; Bordonaba-Juste, Lucia-Palacios, and PoloRedondo 2012). In addition, the digital marketing environment is changing rapidly, so earlier studies related to this topic might not be valid anymore. This study focuses on the utilisation of digital marketing tools from micro-enterprises' viewpoint and, in particular, practical aspects of this strategy. These tools were examined through key elements of building customer relationships, which are crucial to understanding digital marketing and its impacts on strong customer relationships. It is important for companies emphasize on digital customer relationships management, interaction and development (Sinisalo and Karjaluoto 2007; Tiago and Verissimo 2016; Kierzkowski et al. 1996) and it seems that research is lacking related to the phenomenon in the context of micro-enterprises. The aim of the paper is to get new understanding about micro-enterprises digital marketing tools for building customer relationships. Thus, the research question explored was as follows: How do micro-enterprises utilise digital marketing tools to build customer relationships?

New digital marketing tools can be examined through how they affect the five key aspects of customer relationship development that Kierzkowski et al. (1996) include in their digital marketing model. These elements are attracting customers, engaging customers' interest and participation, retaining customers, learning customers' preferences and relating to customers (Kierzkowski et al. 1996). These five strategies served as the basis of the preliminary framework (see figure 1) of the present digital marketing study. The digital marketing tools found to be potentially useful for micro-enterprises are presented in the centre of figure 1 . These tools were examined individually from the perspective of each element. Thus, the present study sought to update and extend the above-cited digital marketing model developed by Kierzkowski et al. (1996) in order to reflect the microenterprise context.

\section{Digital Marketing Tools That Build Customer Relationships}

Competitive markets are becoming more complicated, including that customer interfaces are far broader than conventional marketing models assume (Grönroos 2009). The proposed model in figure 1 shows the distinct phases of building customer relationships through digital marketing, with each element containing many different factors that companies have to consider. In the present study, digital marketing refers to the practice of promoting products and services

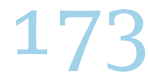


FIGURE 1

Digital Marketing

Tools That Build

Customer

Relationships

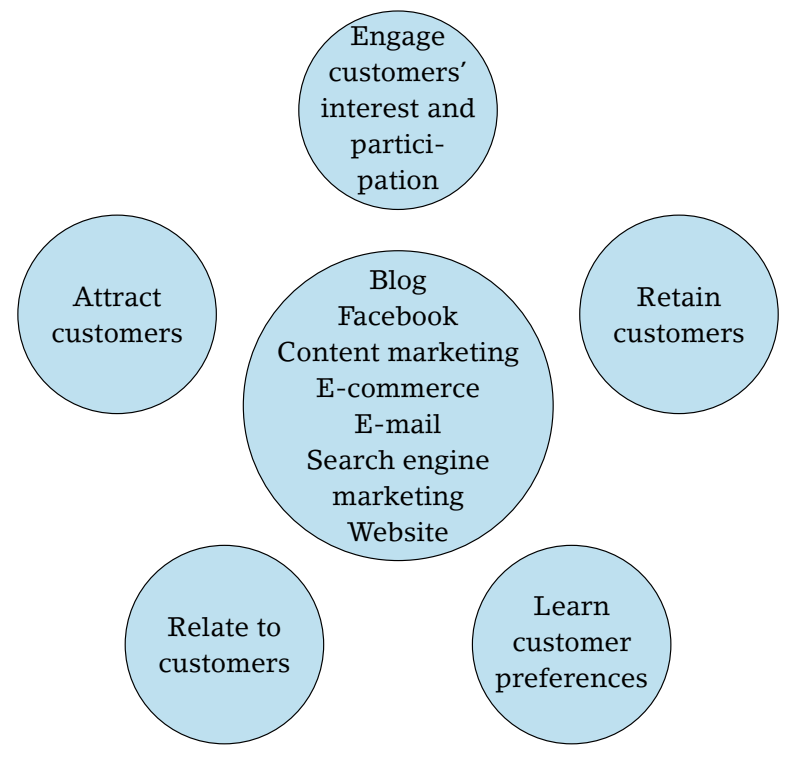

using digital distribution channels via computers, mobile phones, smart phones or other digital devices' (Smith 2012, 86).

\section{BUILDING CUSTOMER RELATIONSHIPS}

The digital marketing model's first element, attracting customers, covers how companies can persuade customers to, for example, visit their website. One of the most beneficial tool in applying this strategy is search engine optimisation (Teo 2005). The next element, engaging customers' interest and participation, has the objective of promoting interactions and transactions after customers have been persuaded to visit the website. For example, content marketing and e-commerce can be used as instruments to create interest in engaging in sales transactions and newsletter subscriptions (Teo 2005).

The third element, retaining customers, focuses on getting customers to return to company websites. Constant maintenance of communication is necessary when building customer relationships, and continuous utilisation of resources is essential in digital marketing (Kierzkowski et al. 1996). Learning customer preferences involves collecting information on present and potential customers with, for example, online surveys. Providing customised products and services can generate unique feelings among customers. However, many companies still consider collecting information about customer preferences difficult and expensive (Teo 2005).

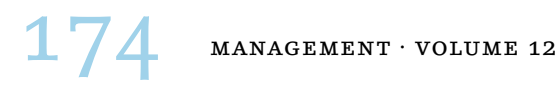


Relating to customers means individualised communication, which is a key strategy in providing superior value to customers. This fifth element is critical since, on many occasions, it is required as digital marketing's starting point to enhance existing business activities (Kierzkowski et al. 1996). However, companies may lack information on, and knowledge of, customer preferences - on which they could base their customised strategies. E-mail is an example of one of the fifth element's digital tools (Teo 2005). The digital marketing tools potentially appropriate for micro-enterprises are described in the next section in greater detail in relation to the above customer relationship elements.

\section{DIGITAL MARKETING TOOLS}

Creating an appropriate website is required for successful digital marketing (Rahimnia and Hassanzadeh 2013). Eid and El-Gohary (2013) state that websites as a digital tool contain opportunities to reach many markets rapidly and economically. Content marketing has also become one of the most crucial strategies for companies that want to maximise profit by advertising products and services in competitive and constricted markets (Rahimnia and Hassanzadeh 2013). Website and content marketing appear to influence two elements of building customer relationships: engaging customers' interest and participation and retaining customers. The active and constant renewal and dynamic development of website content are crucial strategies since consumers do not return to websites without a reason (Teo 2005).

Search engine marketing is an extremely beneficial tool for attracting customers to websites (Teo 2005). This tool exploits Internet search engines to lead consumers to selected websites (Rangaswamy, Giles, and Seres 2009). Search engine marketing can be divided into two different search engine strategies: optimisation and advertising. In search engine advertising, companies pay search engines to include links to their website. In search engine optimisation, companies work to raise their websites as high as possible in the search engine's organic results (Dou et al. 2010). Taiminen and Karjaluoto (2015) state that search engine marketing is one of the most useful tools for small and medium-sized companies, so this could also be assumed to be true for micro-enterprises.

Kaplan and Haenlein (2010) define social media as 'a group of Internet-based applications that are built on the ideological foundations of Web 2.0, which allows the creation and exchange of usergenerated content.' Social media enables more effective direct con-

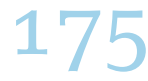


nection and communication at the right time at a relatively small expense, which is more effective than traditional tools are (Kaplan and Haenlein 2010). It can help small businesses to communicate cost effectively with customers on a global scale (Jones, Borgman, and Ulusoy 2015). McCann and Barlow (2015) noted that better communication and marketing of products/services is one of the main benefits identified from the use of social media among the small business. As an outcome, social media is perceived as performing a central role in current companies' marketing and business undertakings (Atanassova and Clark 2015; Kirtiş and Karahan 2011). Social media as a digital tool can be utilised to strengthen most of the five relationship elements. Blogging is a part of social media in which companies retain a relatively high level of control, as blogs are usually located on company websites. With blogs, companies can create meaningful content and influence two elements: engaging customers' interest and participation and retaining customers (Taiminen and Karjaluoto 2015). One great advantage of Facebook is customers' ability to communicate directly with companies about their needs. Via Facebook, companies can learn about their customers, which contributes to learning customer preferences, as well as relating to these customers (Hanson, Wrangmo, and Soilen 2013). Taiminen and Karjaluoto (2015) mention that Facebook is a useful tool in getting customers to commit, which refers to the third element, retaining customers. Facebook is also used in interactive communication with potential customers, which relates to the first element, attracting customers (Valos et al. 2016).

Successful $e$-mail marketing can help companies to collect customer feedback easily and create and introduce advertisements of new products and services, while increasing communication between companies and customers (Dehkordi et al. 2012). According to Simmons (2007), e-mails can facilitate brand encounters and deepen relationships with loyal customers. Companies seek to customise their communication according to individual preferences, and e-mail marketing offers opportunities to customise and individualise communication (Merisavo and Raulas 2004). With e-mails, companies can influence several elements: retaining customers, learning their preferences and relating to them (Dehkordi et al. 2012). This tool can also be used to guide customers to websites, which is a part of the first element (Simmons 2007).

Wilson and Abel (2002) define e-commerce as 'the use of electronic media such as the Internet to transact businesses. This tool enables companies to sell products, services and information online (Wil- 
son and Abel 2002). The advantages of e-commerce are, for example, more fluent business processes, more developed customer services and decreased expenses in marketing and purchase transactions (Jahanshahi, Zhang, and Brem 2013). E-commerce is a crucial part of the second element of building customer relationships since the objective of attracting customers' interest and participation is to achieve interactions or business transactions after customers have been enticed to websites (Teo 2005).

Pelau and Zegreanu (2010) state that mobile marketing strengthens traditional communication tools by achieving better results. Mobile phone is a pivotal commodity nowadays and the increasing number of smart phones have created remarkably wider opportunities to companies to reach and serve consumers and to interact with them (Persaud and Azhar 2012). Mobile marketing is an interactive channel, which provides direct and personal communication, and thus, according to $\mathrm{Xu}, \mathrm{Liao}$, and $\mathrm{Li}$ (2008), allows companies to develop even deeper customer relationships. The channel is not reliant of time and place and hereby it creates an opportunity to target consumers accurately (Persaud and Azhar 2012).

The usage of social networks such as Facebook and YouTube creates a crucial opportunity to integrate and expand companies' marketing strategy with mobile marketing strategy. Smart phones have ability to combine for example Bluetooth, location based marketing and other technologies to provide superior customer experiences. Companies have opportunity to serve customers by using versatile media content such as text, voice and videos, but also various applications. Mobile marketing is relatively easy and inexpensive way to reach consumers (Persaud and Azhar 2012). Watson, McCarthy, and Rowley (2013) verify that mobile marketing as a channel supports many interactive activities in a cost-effective way.

\section{Methodology}

The present study sought to contribute to a more in-depth understanding of micro-enterprises' current utilisation of digital marketing tools when building customer relationships. To achieve this objective, the empirical study was conducted as a case study (Stake 1995; 2000; Yin 2003). More specifically, the research was based on a collective case study (Stake 1995) since case studies can integrate a deeper and more reflective understanding of organisations (Rendtorff 2015). This method involves theory construction and satisfies the need to understand real-life phenomena (Riege 2003). In the case selection, authors chose two digital marketing service providers 
that have broad perspective about the phenomena. Study utilizes instrumental case study approach to provide insight into an issue. In instrumental case study, case serves to help to understand phenomena or relationships within it. Often an issue question is of more interest to the researcher than is the case. When use more than one instrumental cases, the work can call as collective case study (Stake 1995).

The data collection was conducted through explorative theme interviews. Interviews constitute a flexible research method that is justified when conversations are needed to address the research question in a broader context (Hirsjärvi and Hurme 2008, 35). Theme interviews require carefully prepared questions that are used consistently and systematically within the bounds of verified themes ( $\mathrm{Qu}$ and Dumay 2011). The research goal necessarily determines the number of interviewees (Hirsjärvi and Hurme 2008, 58-9), so, in the present study, two interviews were conducted, and the questions and themes were developed based on the preliminary framework described previously. These themes were the five elements of building customer relationships, as well as micro-enterprises and their perspective on digital marketing.

The interviews were conducted in March and November 2016. One interviewee (Interviewee $\mathrm{X}$ ) is a digital marketing expert of a company that provides digital marketing services for micro-enterprises, among other types of firms. Interviewee $\mathrm{X}$ has had broad experience in the current state of digital tool utilisation in micro-enterprises. The other interviewee (Interviewee $\mathrm{Z}$ ) is a private corporate consultant who specialises in helping solo-entrepreneurs to increase sales and conduct digital marketing. A full 95 percent of Interviewee Z's customers are micro-enterprises, so this participant brought a particularly extensive knowledge of solo-entrepreneurs' current practices to this study. The in-depth interviews were conducted by the first author, and the recorded data was transcribed. The interview transcripts were analysed according to the themes, and the quotations in the results section below were directly extracted from the interviews.

\section{Results}

According to interviewee X, owner-manager's human capital is essential to micro-enterprises. If the entrepreneur has knowledge of the digital tool alternatives and how they can be utilized, positive impact can be accomplished. Interviewee $\mathrm{Z}$ mentions also flexibility as micro-enterprises' positive aspect. In addition both interviewees

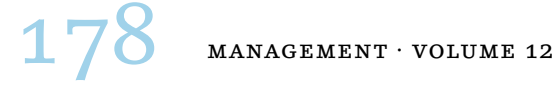


state the resource problems and the lack of know-how in microenterprises' are negative factors and that most of the time is cantered in the core business.

According to interviewee $\mathrm{X}$ micro-enterprises understand the importance of the first element, attracting customers, and they invest in it with different weights. Interviewee $\mathrm{Z}$ notices that also smaller micro-enterprises, solo-entrepreneurs, invest in it relatively much compared to other elements. For example, Facebook is relatively well-known digital tool, which is exploited among micro-enterprises independently.

Especially for example Facebook, they (micro-enterprises) have took it in their business more or less, either that they have with their own profiles pointed out, where they operate. [Interviewee $\mathrm{X}]$

Search engine marketing and analytics tools are the most costefficient and applicable digital tools to micro-enterprises according to the interviews. Interviewee $\mathrm{Z}$ adds also blogs, videos and e-mail, but states that micro-enterprises do not utilize e-mail efficiently enough and the execution is generally done unsuccessfully,

In developing the second element, engaging customer interest and participation, the interviewees emphasized the significance of websites especially for micro-enterprises. According to the interviewee $\mathrm{X}$, micro-companies recognize the importance of the element, but interviewee $\mathrm{Z}$ states that it is common that solo-entrepreneurs have only their contact information in their website.

The recognized tools in the preliminary framework for the second element were blogs, content marketing, website and e-commerce. According to the interviews, other tools utilized by micro-enterprises are videos, which are published in YouTube, search engine optimization and e-mail. Interviewees explained that e-commerce is not very common digital tool among micro-enterprises excluding companies, which businesses' focus purely on e-commerce.

At the third element, retaining customers, the interviewee $\mathrm{X}$ would separate micro-enterprises that have operated longer and younger companies, start-ups. Micro-enterprises that have operated longer understand the importance.

We have to separate long-operated micro-enterprises and then this kind of start-ups, which do not have that much customer base. Especially those, who have history [...] are ready to put resources on it. [Interviewee $\mathrm{X}$ ]

Potential tools recognized in the theoretical framework were blogs, 
Facebook, content marketing, e-mail and website. Interviewee $\mathrm{Z}$ states that in many cases understanding content marketing as a whole is missing. According to the interviewee $\mathrm{X}$, micro-enterprises also utilize intranet, where part of a website is not available for everyone.

As in the previous element, also in learning customer preferences, both interviewees suggested separation among micro-enterprises. Companies that have operated longer invest and understand the importance of the element more profound. The interviewee $\mathrm{X}$ added that micro-enterprises are all the time more interested of automatization in order to figure out, in which products the customers have been acquainted on the website. Hereby customers can be approached through specific product.

All the time we are going towards that the companies try like to know customers secretly. [Interviewee X]

According to the interviewee $\mathrm{X}$, companies cannot only utilize digital marketing in learning customers' preferences - the element goes deeper into personal level. Surveys through e-mails and Facebook in learning about customers are rarely utilized.

According to the interview the fifth element, relating to customers, is an element that is often left behind in micro-enterprises.

Those (entrepreneurs) that have understood the situation, they try to give personal service, but in digital form too little; we are talking about 10 percent. There is not yet understanding that customers could be served there. It is not understood to utilize communication with the customers. [Interviewee Z]

Recognized tools in the theoretical framework were Facebook and e-mail. According to the interviewee $\mathrm{X}$ a used tool among microenterprises is also intranet. Interviewee $\mathrm{Z}$ points out also social media's power, particularly Facebook's.

The significance of mobile marketing is enormous for all companies, also for micro-enterprises, according to the interviewee $\mathrm{X}$. Nowadays, companies do not perform marketing, which is not compatible to mobile marketing. According to interviewee, companies started to pay attention to mobile marketing in 2013 and the channel has had a great role ever since. Mobile marketing became popular, when making of a responsive website became cost effective.

\section{Discussion}

Our study's prior target was to increase knowledge of micro-enterprises' current utilization of new digital marketing tools in building 
TABLE 1 Digital Marketing Tools for Micro-Enterprises in Building Customer Relationships

\begin{tabular}{lll}
\hline Category & $\begin{array}{l}\text { Theoretically recognised } \\
\text { digital tools }\end{array}$ & Utilised digital tools \\
\hline Attract customers & Facebook & Facebook \\
& Search engine Marketing & Search engine Marketing \\
& E-mail & E-mail \\
& & Blog \\
& & Video \\
& Analytics tools \\
\hline Engage customers' & Blog & Blog \\
interest and & Content marketing & Content marketing \\
participation & Website & Website \\
& E-commerce & Video \\
& & Search engine optimisation \\
& & E-mail \\
\hline Retain customers & Blog & Blog \\
& Facebook & Facebook \\
& Content marketing & Content marketing \\
& E-mail & E-mail \\
& Website & Website \\
& & Intranet \\
\hline Learn customer & Facebook & Analytics tools \\
preferences & E-mail & \\
\hline Relate to customers & Facebook & Facebook \\
& E-mail & E-mail \\
& & Intranet \\
\hline
\end{tabular}

their customer relationships. To answer research questions, the new digital marketing tools were examined through five elements of building customer relationships.

Our framework on micro-enterprises' digital marketing tools in building customer relationships is a new approach in discussion on digital marketing tools. Also micro-enterprises' owner-managers' human capital and its' effect on digital marketing is valuable viewpoint to scientific conversations. Micro-enterprises' digital marketing is managerially and societally current issue, which has been underexplored so far. Our case study offers perspective for microenterprises about practical digital marketing tools in different elements of building customer relationships. Empirical results showed that entrepreneur's personal features affect whether the enterprise will utilize digital tools and if the enterprise will co-operate with marketing companies.

In the theoretical framework (table 1), digital marketing tools for micro-enterprises are presented under the elements of build- 
ing customer relationships. Empirical results showed that microenterprises invest relatively extensively to the first element, attracting customers. The interviews supported partly the earlier knowledge as Facebook, search engine marketing and e-mail were recognized as potential tools in developing the element. However, empirical results added also new digital tools such as blogs, videos and analytics tools to the element. Hauser (2007) emphasizes that analytics tools should became companies' standard tool in digital marketing as the tool demands companies to utilize data in order to understand customers in their every lifecycle phase. In 21st century, immediate interactive marketing demands utilization of customer information so that personal customer relationships can be built in acquiring new customers (Hauser 2007). According to Waters and Jones (2011) videos strengthen the idea of companies' products and services, give personality to the organization and most of all build brand. Feguson (2008) continues that wide spectrum of organizations are going towards social media, such as YouTube, in order to spread news and videos.

Also in the second element, engaging customers' interest and participation, earlier literature and empirical results partly support each other. Empirical results showed that in general, micro-enterprises understand the importance of the element and they invest in it, but especially solo-entrepreneurs lacking invest on it. Common tools between earlier knowledge and empirical results were blogs, content marketing and website, which indicate that these tools are still relevant. Empirical results showed that micro-enterprises also use currently videos, search engine optimization and e-mail. Nevertheless, e-commerce, which was recognized as applicable tool in theoretical framework, was not mentioned in empirical results. According to the interviewees one reason is that micro-enterprises' are lacking resources and Jahanshahi et al. (2013) write that one disadvantage of e-commerce is high costs of user support.

Blogs, Facebook, content marketing, e-mail and website were recognized earlier as potential tools for micro-enterprises in the third element, retaining customers, and digital tools are also utilized in the companies. The empirical material completed the earlier knowledge with intranet. Intranet can be defined as dynamic and personalized gate in network, which belongs exclusively to the company. With intranet companies have opportunity to face the customers' information needs (Neill and Richard 2010). According to the empirical results, long-operated micro-enterprises invest more and understand the importance of the element compared to start-ups. 
In learning customer preferences, theoretically recognized digital tools for micro-enterprises were Facebook and e-mail. Contrary, empirical material showed that micro-enterprises utilize only analytics tools in the element. Micro-enterprises do not usually utilize analytics tools without external help because the tools require knowledge of developing the database and controlling the quality of information (Hauser 2007).

According to Dehkordi et al. (2012), e-mail marketing helps companies to get feedback from customers easily. However, empirical results showed that analytics tools have a greater role in learning customer preferences - e-mail is not no longer current tool in the element. Hauser (2007) says that analytics tools are crucial particularly in retaining current, the most profitable customers. Hanson, Wrangmo, and Soilen (2013) state that one of the greatest benefit in Facebook is customers' opportunity to communicate with companies of their need and wants. According to the empirical results, companies are trying to get information about customers without customers' knowledge. Generally, micro-enterprises utilize relatively little digital tools in the fourth element.

In theoretical part, e-mail and Facebook were recognized as applicable digital tools in relating to customers. Empirical results supported the theoretical part, as micro-enterprises utilize e-mail and Facebook in developing the element. Merisavo and Raulas (2004) have written earlier that e-mail marketing should concentrate to deepen the relationships with loyal customers and the e-mail communication should be built based on individual preferences. This can be achieved by using e-mail in development of the element. In addition, intranet was in empirical results the most cost-efficient and applicable tool for the element: intranet can be called as personalized tool (Neill and Richard 2010). Micro-enterprises do not invest much to the element in question. In addition, the quality of mobile sites affect greatly consumers' attitude towards the brand (Watson et al. 2013).

To conclude, micro-enterprises have a wide range of opportunities to utilise digital marketing tools, and companies that use marketing services exploit tools relatively extensively based on the present study's findings. Nevertheless, solo-entrepreneurs appear to neglect a long-term focus on digital marketing tools even though they have many opportunities to benefit from digitalisation. Micro-enterprises have to take into account that their owner-managers' human capital and knowledge of these tools have a great impact on digital marketing and its success. Different digital tools have different impacts on 
companies' digital marketing objectives. Micro-enterprises need to consider how they can use different digital tools in order to build their customer relationships more efficiently. Micro-enterprises also should concentrate on ensuring that all their digital tools are integrated with each other and that their marketing strategy is systematic, persistent and compatible to mobile marketing.

One of the most important digital tools for micro-enterprises, based on the present research's results, is website, as micro-enterprises do not generally have a separate sales department. In addition, content marketing is cost-effective and valued highly, while email appears to be the most commonly used tool in all five customer relationship elements. Thus, e-mail can be considered a versatile tool. Micro-enterprises need to emphasise learning customer preferences and relating to customers, as the significance of these elements is usually not adequately understood. In other words, microenterprises focus, in general, more on acquiring customers, and these firms do not put enough stress on committing to customers and retaining their loyalty.

We are acknowledged that study has some limitations, primarily about generalizing the findings of instrumental cases regarding the heterogeneous group of micro-enterprises. The small number of cases limits generalizations from this study's findings. Moreover, some of the findings may be case-specific or context-specific. Therefore, the findings of the study cannot be directly generalised to other micro-enterprises or business contexts and depend on the time of the data collection. Thus, in the future studies more empirical data should be collected to able to confirm the findings presented in this study. However, the results offer preliminary insights for facilitating future studies. We are aware that mobile strategy is a key aspect of digital marketing (Lamberton and Stephen 2016). In addition, responsive design of websites, addressing communities on social media (Kaplan and Haenlein 2011) and viral marketing (Kaplan and Haenlein 2011; Hinz et al. 2011) are all relevant aspects of digital marketing which we have not been discussed much in our study. Thus, in the future studies these aspects of digital marketing could be discussed in way that is more detailed. In addition, this study has not discussed newer state-of-the art platforms such as Snapchat, Instagram or Pinterest which have emerged in the situation when consumers are 'constantly connected' through their mobile phones and which has changed their roles from consumer to acting also advertiser and promoter (Lamberton and Stephen 2016). This changed situation offers new business potential for micro-enterprises and 
should be investigated in the future studies. Moreover, studying the phenomenon in business-to-consumer and business-to-business contexts would bring new angle to the discussion of digital marketing tools for building customer relationships.

\section{References}

Atanassova, I., and L. Clark. 2015. 'Social Media Practices in SMe Marketing Activities: A Theoretical Framework and Research Agenda.' Journal of Customer Behaviour 14 (2): 163-83.

Barnes, D., F. Clear, G. Harindranath, R. Dyerson, L. Harris, and A. Rea. 2012. 'Web 2.0 and Micro-Businesses: An Exploratory Investigation.' Journal of Small Business and Enterprise Development 19 (4): 687711.

Bordonaba-Juste, V., L. Lucia-Palacios, and Y. Polo-Redondo. 2012, 'The Influence of Organizational Factors on E-Business Use: Analysis of Firm Size.' Marketing Intelligence \& Planning 30 (2): 212-29.

Clark, D. N., and H. Douglas. 2014. 'Micro-Enterprise Growth: Lessons from Home-Based Business in New Zealand.' Small Enterprise Research 21 (1): 82-98.

Dehkordi, G. J., S. Rezvani, M. S. Rahman, F. F. N. Nahid, and S. F. Jouya. 2012. 'A Conceptual Study on E-Marketing and Its Operation on Firms' Promotion and Understanding Customers' Response.' International Journal of Business and Management 7 (19): 114-24.

Devins, D., J. Gold, S. Johnson, and R. Holden. 2005. 'A Conceptual Model of Management Learning in Micro Businesses: Implications for Research and Policy.' Education \& Training 47 (8-9): 540-51.

Donnelly, C., G. Simmons, G. Armstrong, and A. Fearne. 2015. 'Digital Loyalty Card "Big Data" and Small Business Marketing: Formal versus Informal or Complementary?' International Small Business Journal 33 (4): 422-42.

Dou, W., K. Lim, N. Zhou, and N. Cui. 2010. 'Brand Position Strategy Using Search Engine Marketing.' MIS Quarterly 34 (2): 261-79.

Eid, R., and H. El-Gohary. 2013. 'The Impact of E-Marketing Use on Small Business Enterprises' Marketing Success.' Service Industries Journal 33 (1): 31-50.

European Commission. 2003. 'Commission Recommendation of 6 May 2003 Concerning the Definition of Micro, Small and Medium-Sized Enterprises (2003/361/EC).' Official Journal of the European Union L $124,36-41$.

Ferguson, R. 2008. 'Word of Mouth and Viral Marketing: Taking the Temperature of the Hottest Trends in Marketing.' Journal of Consumer Marketing 25 (3): 179-82.

Gilmore, A., D. Gallagher, and S. Henry. 2007. 'E-Marketing and SMEs: Operational Lessons for the Future.' European Business Review 19 (3): 234-47. 
Grönroos, C. 2009. 'Marketing as Promise Management: Regaining Customer Management for Marketing.' The Journal of Business \& Industrial Marketing 24(5): 351-9.

Hansson, L., A. Wrangmo, and K. Solberg Søilen. 2013. ‘Optimal Ways for Companies to Use Facebook as a Marketing Channel.' Journal of Information, Communication \& Ethics in Society 11 (2): 112-26.

Hauser, W. J. 2007. 'Marketing Analytics: The Evolution of Marketing Research in the Twenty-First Century.' Direct Marketing: An International Journal 1 (1): 38-54.

Hinz, O., B. Skiera, C. Barrot, and J. U. Becker. 2011. 'Seeding Strategies for Viral Marketing: An Empirical Comparison.' Journal of Marketing 75 (6): 55-71.

Hirsjärvi, S., and H. Hurme. 2008. Tutkimushaastattelu: Teemahaastattelun teoria ja käytäntö. Helsinki: Gaudeamus Helsinki University Press.

Jahanshahi, A. A., S. X. Zhang, and A. Brem. 2013. 'E-Commerce for smes: Empirical Insights from Three Countries.' Journal of Small Business and Enterprise Development 20 (4): 849-65.

Jones, N., R. Borgman, and E. Ulusoy. 2015 'Impact of Social Media on Small Businesses.' Journal of Small Business and Enterprise Development 22 (4): 611-32.

Kaplan, A. M., and M. Haenlein. 2010. 'Users of the World, Unite! The Challenges and Opportunities of Social Media.' Business Horizons 53 (1): 59-68.

- 2011. 'Two Hearts in Three-Quarter Time: How to Waltz the Social Media/Viral Marketing Dance.' Business Horizons 54 (3): 253-63.

Kierzkowski, A., S. McQuade, R. Waitman, and M. Zeisser. 1996. 'Marketing to the Digital Consumer.' McKinsey Quarterly 2:180-3.

Kirtiş, A. K., and F. Karahan. 2011. 'To Be Or Not to Be in Social Media Arena as the Most Cost Efficient Marketing Strategy after the Global Recession.' Procedia: Social and Behavioral Sciences 24:260-8.

Lamberton, C., and A. T. Stephen. 2016. 'A Thematic Exploration of Digital, Social Media, and Mobile Marketing: Research Evolution from 2000 to 2015 and an Agenda for Future Inquiry.' Journal of Marketing $80(6): 146-72$.

Leeflang, P. S., P. C. Verhoef, P. Dahlström, and T. Freundt. 2014. 'Challenges and Solutions for Marketing in a Digital Era.' European Management Journal 32 (1): 1-12.

Lipiäinen, H. 2014. 'Digitization of the Communication and its Implications for Marketing.' Doctoral dissertation, Jyväskylä University, Jyväskylä.

McCann, M., and A. Barlow. 2015. 'Use and Measurement of Social Media for smes.' Journal of Small Business and Enterprise Development 22 (2): 273-87.

Merisavo, M., and M. Raulas. 2004. 'The Impact of E-Mail Marketing on 
Brand Loyalty.' The Journal of Product and Brand Management 13 (7): 498-505.

Neill, W. D., and J. E. Richard. 2012. 'Intranet Portals: Marketing and Managing Individuals' Acceptance and Use.' Australasian Marketing Journal 20 (2): 147-57.

Pelau, C., and P. Zegreanu. 2010. 'Mobile Marketing: The Marketing for the Next Generation.' Management \& Marketing 5 (2): 101-16.

Persaud, A. and I. Azhar. 2012. 'Innovative Mobile Marketing via Smartphones: Are Consumers Ready?' Marketing Intelligence \& Plan 30 (4): 418-443.

Qu, S. Q., and J. Dumay. 2011. 'The Qualitative Research Interview.' Qualitative Research in Accounting \& Management 8 (3): 238-64.

Rahimnia, F., and J. F. Hassanzadeh. 2013. 'The Impact of Website Content Dimension and E-Trust on E-Marketing Effectiveness: The Case of Iranian Commercial Saffron Corporations.' Information \& Management 50 (5): 240-7.

Rangaswamy, A., C. L. Giles, and S. Seres. 2009. 'A Strategic Perspective on Search Engines: Thought Candies for Practitioners and Researchers.' Journal of Interactive Marketing 23 (1): 49-6o.

Rendtorff, J. D. 2015. 'Case Studies, Ethics, Philosophy, and Liberal Learning for the Management Profession.' Journal of Management Education 39 (1): 36-55.

Riege, A. M. 2003. 'Validity and Reliability Tests in Case Study Research: A Literature Review with "Hands-on" Applications for Each Research Phase.' Qualitative Market Research 6 (2): 75-86.

Simmons, G. J. 2007. "“I-branding:" Developing the Internet as a Branding Tool.' Marketing Intelligence \& Planning 25 (6): 544-62.

Sinisalo, J., and H. Karjaluoto. 2007. 'Mobile Customer Relationship Management: A Communication Perspective.' International Journal of Electronic Customer Relationship Management 1 (3): 242-57.

Sinisammal, J., M. Muhos, L. Eskola, and E. Niinikoski. 2014. Oulun eteläisen alueen mikroyrittäjien hyvinvointi: kysely-ja haastattelututkimus. Oulu: Oulun Yliopisto.

Smith, K. 2012. 'Longitudinal Study of Digital Marketing Strategies Targeting Millennials.' Journal of Consumer Marketing 29 (2): 86-92.

Stake, R. E. 1995. The Art of Case Study Research. Thousand Oaks, cA: Sage.

- 2000. 'Case Studies.' In Handbook of Qualitative Research, 2nd ed., edited by N. K. Denzin and Y. S. Lincoln, 435-54. Thousand Oaks, cA: Sage.

Taiminen, H. M., and H. Karjaluoto. 2015. 'The Usage of Digital Marketing Channels in smes.' Journal of Small Business and Enterprise Development 22 (4): 633-51.

Teo, T. S. H. 2005. 'Usage and Effectiveness of Online Marketing Tools 
among Business-to-Consumer (в2с) Firms in Singapore.' International Journal of Information Management 25 (3): 203-13.

Tiago, M. T. P. M. B., and J. M. C. Verissimo. 2014. 'Digital Marketing and Social Media: Why Bother?' Business Horizons 57 (6): 703-8.

Valos, M. J., H. F. Habibi, R. Casidy, C. B. Driesener, and V. L. Maplestone. 2016. 'Exploring the Integration of Social Media within Integrated Marketing Communication Frameworks.' Marketing Intelligence \& Planning 34 (1): 19-40.

Waters, R. D., and P. M. Jones. 2011. 'Using Video to Build an Organization's Identity and Brand: A Content Analysis of Nonprofit Organizations' YouTube Videos.' Journal of Nonprofit \& Public Sector Marketing 23 (3): 248-68.

Watson, C., J. McCarthy, and J. Rowley. 2013. 'Consumer Attitudes towards Mobile Marketing in the Smart Phone Era.' International Journal of Information Management 33 (5): 840-9.

Wilson, S. G., and I. Abel. 2002. 'So You Want to Get Involved in ECommerce.' Industrial Marketing Management 31 (2): 85-94.

$\mathrm{Xu}, \mathrm{D}$. J., S. S. Liao, and Q. Li. 2008. 'Combining Empirical Experimentation and Modeling Techniques: A Design Research Approach for Personalized Mobile Advertising Applications.' Decision Support Systems 44 (3): 710-24.

Yrityskatsaus 2014: murroksia ja uudistumista. 2014. Helsinki, Finland: Työ- ja Elinkeinoministeriö.

Yin, R. K. 2003. Case Study Research: Design and Methods. 3rd ed. Thousand Oaks, cA: Sage.

This paper is published under the terms of the AttributionNonCommercial-NoDerivatives 4.o International (CC BY-NC-ND 4.0) License (http://creativecommons.org/licenses/by-nc-nd/4.o/). 